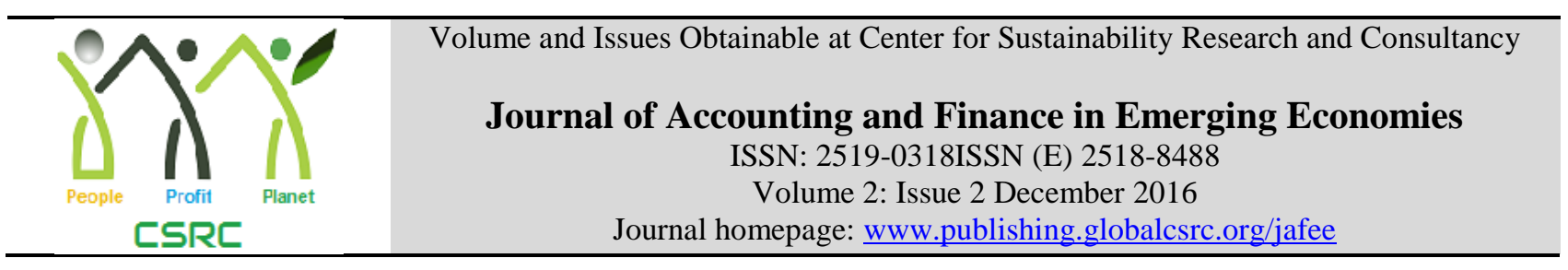

\title{
Influence of Creative Accounting on Reliability and Objectivity of Financial Reporting (Factors Responsible for Adoption of Creative Accounting Practices in Pakistan)
}

\author{
${ }^{1}$ Maria Shahid, ${ }^{2}$ Hina Ali \\ ${ }^{1}$ Lecturer, Department of Management Sciences, The Women University Multan Pakistan \\ mariashahid26@yahoo.com \\ ${ }^{2}$ Assistant Professor, Department of Economics, The Women University Multan Pakistan \\ hinaali_me@yahoo.com
}

\begin{abstract}
ARTICLEDETAILS
History

Revised format: Nov 2016

AvailableOnline: Dec 2016

\section{Keywords}

Creative Accounting,

Agency Problem,

Corporate Governance,

Company's Ethical Values,

Company's Future

Orientation,

Financial Reporting

JEL Classification:

M49, G34

ABSTRACT

Intellectual modifications (creative accounting) in financial reports to make them attractive are very emerging and vastly accepted practices around the globe. But these practices are deceiving and unethical. This study aims to explore the factors encourage the adoption of creative accounting practices like agency problem, corporate governance, company's ethical value, company's future orientation etc. as well as how these practices affect the reliability and objectivity of financial reporting. This research is an empirical research and data is collected from accounting and management professionals of manufacturing industry of Punjab via structured questionnaire. Convenient sampling technique used to select sample size and SPSS software used for data analysis. Results of this research explored the positive association between agency problem and creative accounting while corporate governance, company's ethical value, company's future orientation have negative impact on creative accounting. It is also verified that creative accounting has significant negative impact on reliability as well as objectivity of financial reporting. Results of this study will assist the company's management how to control adverse influence of these manipulative activities on reliability and objectivity of financial reports as well as provide literacy to investors to be aware of such extensively using speculative activities. Limitations of this study are that it is only considering few factors as well as manufacturing industry of Punjab.
\end{abstract}

(C) 2016 The authors, under a Creative Commons Attribution-

NonCommercial 4.0

Corresponding author's email address: mariashahid26@yahoo.com

Recommended citation:Shahid, M., Ali, H.(2016). Influence of Creative Accounting on Reliability and Objectivity of Financial Reporting (Factors Responsible for Adoption of Creative Accounting Practices in Pakistan).Journal of Accounting and Finance in Emerging Economies, 2(2) 75-82 


\section{Introduction}

Accounting is an essential practice of every business and used by stakeholders to make different types of decisions on available financial information. It is used for final reporting of a business entity that depicts the true picture of business to everyone who has interest in organization business. But now- a-days, fierce competition and tough economic environment are few factors responsible for business entities to getting involved in manipulation of their financial data to make their financial reports attractive and try to cover up the losses of business. Due to such practices, investors get deceived and it becomes difficult to gauge out the alteration even by auditors because these manipulative practices are adopted after identifying gaps in accounting standards and making them fit among these standards. Very emerging concept of making alteration in books of accounts to make deceptive financial reports is known as creative accounting. Very common statement that is found at the start of the final report booklet of each business entity that reports are prepared according to accounting principles like Generally Accepted Accounting Principles (GAAP),International Accounting Standards (IAS), International Financial Reporting Standards (IFRS) etc. and presenting the real facts and figures about business financial health as well as profitability. But the game behind that working is speculative. There is a lot of difference between practices and theories. And the technique used to make such speculation is called creativity in accounting.

DeFond and Park in 1997 said that both creative accounting and earning management alternatively has known as smoothing company's income while Amat and Gowthrope (2004), claimed that creative accounting is a European term and referred to earning management in US. It is also known as window dressing, makeover of financial reports and big bath accounting. Whatever the term is used, but the purpose behind is decorating financial reports to deceive the stakeholder's most commonly external stakeholders to expose the business entity as a highly attractive investment opportunity for them. But such practices of makeover have short term positive impact and long term negative impact. Mostly companies adopted such deceptive practices when suffering financial distress. A tool is just a tool or a dangerous weapon is depending upon the user and similar statements are given by adopters of creative accounting. Due to this dilemma it is still undecided that use of creativity in accounting is legal or illegal. So researcher defined creative accounting as, "a process of decorating business financial reports in lucrative way by getting benefit from minor flexibility in accounting standards to make investors mouth watered."

Shah (1998) states that management identify and enjoy the gap in accounting rules, regulation and procedure to develop the eye catchy statement's about business current state of affairs to make stakeholders delighted. There are many reasons to adopt creativity in accounting process. It may be done to protect the owner of business according to the free will of owner. It may be adopted by management themselves to get handsome benefit packages, survival of top positions or it may be adopted due to deficiency of accounting standards knowledge or quite possible it is entertained by corporate governance as ethical value in company. But in all cases, risk and danger is clearly known by adopter (Reevee J. et al. 2008). According Ghosh (2010), practices of creative accounting get popularized rapidly not only in developed countries but in developing countries too. While Karim, Fowzia and Rashid study also approved the Ghosh's work and said in their paper that creative accounting is a universal practice and it is not possible to get escape from it.

When accountants try to bring any creativity in accounting records and financial reporting, actually they are playing with elements of accounting records. They overstated the assets value, huge stock of inventory, reduced expenses, change the depreciation method and show the provisions as assets and many more. In short run they make business profitable but after exposure of such creativity, business faces long term losses such as fall in share price, bankruptcy, insolvency etc. Most popular example of 
creative accounting is cases of Enron and WorldCom (2002). Corporate governance, management involvement, ethical values of company, Company's orientation about future, knowledge of accounting standards, external directors, external auditors comment and manipulative behaviors of owners as well as management are few factors considered to be responsible of adopting creative accounting practices. A lot of work has done on this concept but that is just literature. Limited studies are empirical in nature considering only few dimensions that are reason of creative accounting adoption. All the past work either literature or empirical has done in international scenario. No contribution is done for Middle East. These days, creative accounting is practiced universally and claims against it also increasing that it is a way to deceive the investors. The basic purpose of this study is to identify the factors that have influence on adoption of creative accounting practices to make financial reports lucrative in Pakistan. Moreover, it is great dilemma to investigate that either creative accounting in reality is just manipulation of financial reports or it has any positive impact? And what factors are responsible to encourage its adoption? So, through this research researcher will try to reveal out the factor that can be controlled to reduce the negative impact of creative accounting for business as well as stakeholders too. This research will try to explore the effect of agency problem, corporate governance, company's ethical values and company's future orientation on adoption of creative accounting practices as well as identify the relationship between creative accounting and reliability and objectivity of financial reporting.

\section{Literature Review}

"Finding new ways to make alteration in accounting records and final reports with intention to make the reports profitable is known as creative accounting." First time Anglo-Saxon (1970) wrote about creativeaccounting. Jameson in 1988 said that creativity in operation as well as accounting welcomed and in struggle of diversity it causes fraud, miss-presentation but such innovation is according to standards andconform to law but not the spirit of accounting. In 1990, Watts and Zimmerman stated that creativeaccounting can be used positively. Different researchers define it in different ways such as Merchant andRockness said in 1994 that a short term positive impact of managerial actions on business income thatwill be deteriorating in long run is creative accounting. It is also known as aggressive or innovativeaccounting. It is a game of showing half empty glass of water as a half full glass of water. According toCambridge Dictionary; creative accounting is process of using accounting rules cleverly to makefinancial statements that are not describing the right picture of business. While in Longman Dictionaryof Contemporary English it is defined as "adopting an unusual but not an illegal way to makeamendment in complete accounting cycle to make the business accounts better as compared to reality."Creative accounting is basically intentional and logical falsification of business income and assets androot cause of many accounting frauds and scandals. Different terminologies used for such manipulativeactivities in accounting i.e. cooking the books, income smoothing, aggressive accounting, massaging thenumbers, earning management etc. While Shah et al. (2011) claimed that in a critical situation businessentity can use creative accounting as a powerful weapon but it highly depend upon the management andethical values of business that how this practices used at that critical point.

Number of factors like agency problem, company's ethical values, future orientation, corporate governance, internal / external auditors comment, standards etc. that encourage the creative accounting practices to make false financial statements. First variable of interest is agency problem and its impact adoption of creative accounting and on objectivity of final reports. Agency problem arises when managers overvalued their personal benefits over the business/owner's benefits. According Diana and Beattrice research work in 2010, manipulative behaviors of managers for their personal gain encourage the adoption of creative accounting that will be lead them to crisis in future. Valdu and Matis claimed in 2010 that if there is a problem between owners and managers then mangers go for creative accounting. Yadav et al. study in 2014 also support the Diana's research that agency problem is one of the reason to 
practice the creativity in accounting. Sometimes managers want to pay less proportion of profit as tax and dividend and want to keep the major proportion as their own salaries, bonuses and incentives etc. then they go for creative accounting to show handsome statements to get rewards (Junaid and Asif, 2014).

Corporate governance/ top management are responsible to implement the rules and regulations, make decisions and keep an eye on management working. Amat and Gowthrope research in 2004 claim that company's directors involve in unethical practices of creative accounting. Corporate governance is major source of preventing the practices of creative accounting on large scale. Chen (2010) studied the leadership role in earning management and figured out positive influence. C. Jeans (2011) study the impact of corporate governance on adoption of creative accounting practices in China and claimed that composition of board of directors (BOD) influence adoption of earning management. BOD comprises of independent directors, accounting/financial expert helped in monitoring and controlling the manipulation of financial data. As well as study of Sorin et al. (2012) supported the Amat's work and research reveals that directors, managers and corporation structure collectively define corporate governance and if directors frequently conduct well define internal audits then fraudulent practices of creative accounting can be controlled. Yadav's study (2013) exposed that involvement of outsides director may reduce the practices of creative accounting. And more the outside users, less creative accounting practices.

Business ethics define what is right and what is wrong in business perspective. Ethical values of a business play a vital role in adoption or rejection of creative accounting practices. Research of Amat and Gowthorpe (2004) describes that falsification in accounting records is not identified by the investors and misleading them is not a justifiable practice. Shah et al. (2011) study claimed that ethical environment of a company define how and why management use creative accounting as a weapon. If company's ethical values are week that promote the creative accounting practices then company will definitely suffer losses in long term as well as losses goodwill. So making deliberate tampering of financial statements to deceive the investors is highly unethical (Valdu and Cuzdriorean, 2013). Afolabi and Oluseye (2013) conducted research on manufacturing firms of Nigeria. They concluded that financial reporting does have effect on managerial and investment decision making. They also state high transparency means to avoid corporate fraud. Qaisar Ali Malik (2015) also proved the positive relationship between the company's ethical values and manipulative behaviors.

According to Gherai and Balaciu (2011), when manipulation in final reports done then business goodwill is at risk and owner tries to take short term advantage over the large long term cost of fraud scandals. It means company's orientation about achievement of short term goals or gaining long term benefits also one reason to adopt the creative accounting practices. Shah et al. (2011) concluded creative accounting as a weapon which is used by a company in a critical situation by adopting flexibility in its accounting/ reporting regulations. Efiok and Eton (2012) study deeply explain about macro manipulation in financial reporting and its impact on share price and capital market of firm. Furthermore, ultimately it increased the risk of the investor which may cause loss. According Laura et al. study in 2013; understandability, relevance, reliability, objectivity and comparability are qualitative characteristics of financial reports defined by IASB and creative accounting has significant impact on these qualities. Qaisar Ali Malik (2015) study reveals the fact that creative accounting has significant impact on financial reporting but maximum usage by management place question mark on the reliability as well as objectivity of financial reports. 


\subsection{Research Hypothesis}

H1: There is a positive relationship between agency problem and adoption of creative accounting practices.

$\mathrm{H} 2$ : There is a negative relationship between corporate governance and adoption of creative accounting practices.

H3: There is a negative relationship between company's ethical values and adoption of creative accounting practices.

H4: There is a negative relationship between company's future orientation and adoption of accounting practices.

H5: There is a negative relationship between creative accounting and reliability as well as objectivity of financial reporting.

\subsection{Proposed Research Model}

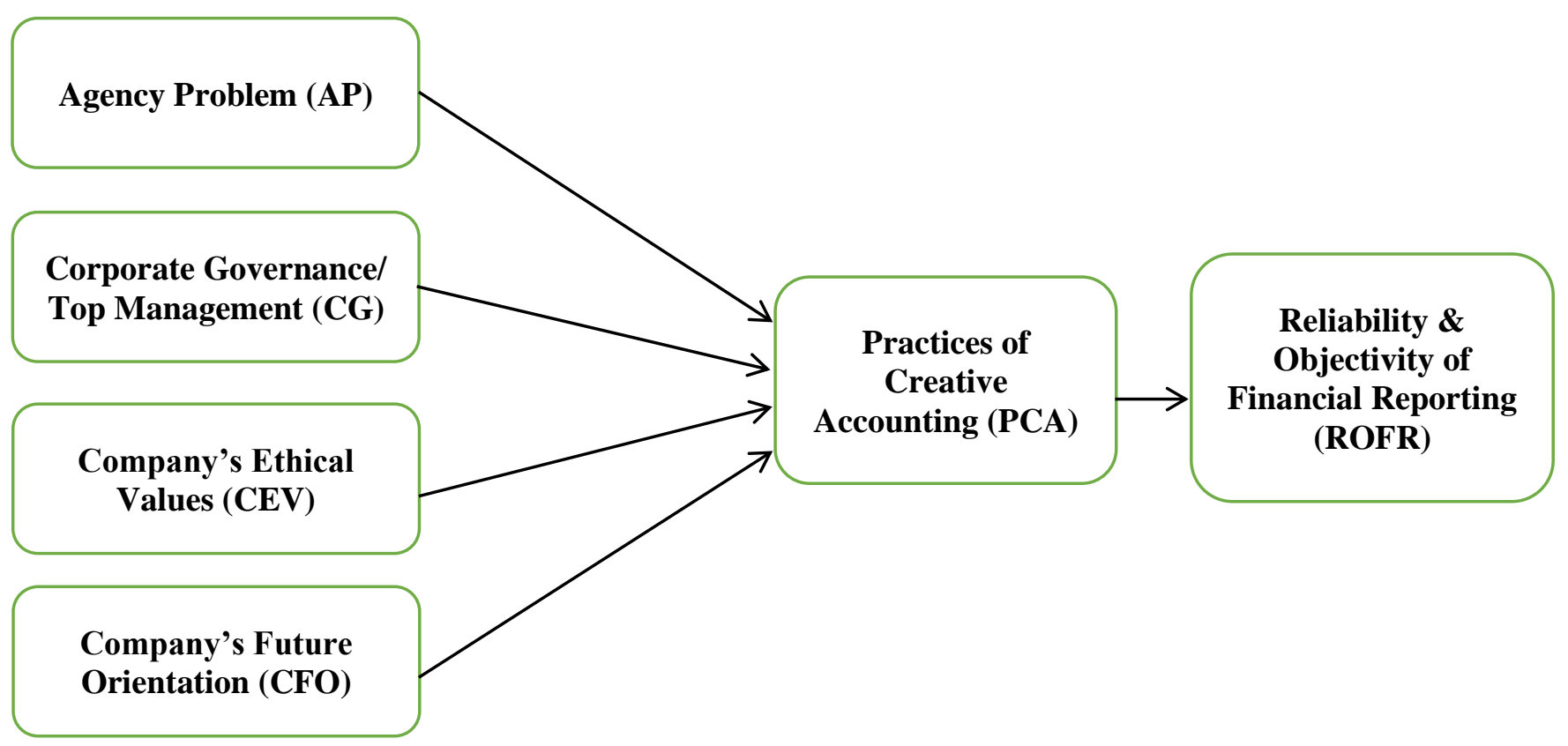

\section{Research Methodology}

This research is empirical research and primary as well as secondary data used to test the hypothesis. Primary data will be collected through structured questionnaire adopted from Lin and Yang study (2006) while secondary data has been collected from various published sources. Research is mainly conducted in Pakistan perspective. Population of research consists of accountants and auditors of manufacturing industry of Pakistan but sample is comprised of 500 accounts and audit professionals of Punjab that are easily accessed but responded by 350. SPSS is used for data analysis. Regression and correlation analysis has done to explore the relationship between defined variables.

\section{Results and Discussion}

\subsection{Reliability Analysis}

The Cronbach alphas of all the variables are more than acceptable and recommended value of 0.50 by Nunnally (1970) and 0.60 by Moss et al. (1998). It shows that all 23 items included in questionnaire are reliable and valid to measure the opinion. 
Table1. Reliability of Measurements Scales

\begin{tabular}{||lcc||}
\hline \multicolumn{1}{|c}{ Scales } & Items & Cronbach Alpha \\
Agency Problem (AP) & 5 & 0.844 \\
Corporate Governance (CG) & 4 & 0.751 \\
Company's Ethical Values (CEV) & 3 & 0.642 \\
Company's Future Orientation (CFO) & 3 & 0.647 \\
Practices of Creative Accounting (PCA) & 4 & 0.782 \\
Reliability \& Objectivity of Financial Reporting (ROFR) & 4 & 0.732 \\
\hline \hline
\end{tabular}

\subsection{Regression and Correlation Analysis Results}

The core purpose of this study is to identify the factors that are responsible for adoption of creative accounting practices in Pakistan as well as how creative accounting influence the reliability and objectivity of financial reporting. Now analysis results will be discussed in the light of literature. First hypothesis constructed on the basis of literature claimed a positive relationship between agency problem and creative accounting practices and results of analysis (Table 2) proves it correct. Result states that moderate significant positive relationship is existed between agency problem and creative accounting $(\mathrm{r}$ $=0.510$ ) and agency problem is $52 \%$ accounted for adoption of creative accounting practices in Pakistan $(\beta=0.523)$.

\section{Table 2: SPSS Analysis Results}

\begin{tabular}{|llcccc|} 
Hypothesis & \multicolumn{1}{c}{ Model Variables } & $\mathbf{\beta}$ & $\mathbf{r}$ & $\mathbf{p}$ & Results \\
H1 & Agency Problem $\rightarrow$ Creative Accounting & 0.523 & 0.510 & 0.000 & supported \\
H2 & Corporate Governance $\rightarrow$ Creative Accounting & -0.380 & -0.370 & 0.001 & supported \\
H3 & Company's Ethical Values $\rightarrow$ Creative Accounting & -0.322 & -0.368 & 0.002 & supported \\
H4 & Company's Future Orientation $\rightarrow$ Creative Accounting & -0.043 & -0.058 & 0.001 & supported \\
H5 & Creative Accounting $\rightarrow$ Reliability \& Objectivity of & -0.462 & -0.515 & 0.003 & supported \\
& Financial Reporting & & &
\end{tabular}

Background of study claimed that strong presence of corporate governance leads towards the controlled/ limited creative accounting in practice. And the results of study in Pakistan scenario proves second hypothesis true. There is a negative association discovered between corporate governance and creative accounting adoption $(r=-0.370)(\beta=-0.380)$. Third hypothesis is constructed as there is a negative relationship between company's ethical values and creative accounting and results supported the literature as well as hypothesis. A moderate but less significant association between company's ethical values and creative accounting $(r=-0.368)$ is discovered in Pakistan scenario $(\beta=-0.322)$. Analysis results are less supportive in case of company's future orientation and creative accounting. Very week relation $(\beta=-0.043)$ is explored between these variables $(r=-0.058)$. Literature claims that there is a significant negative relationship existed between creative accounting practices and reliability and objectivity of financial reporting, results of this study supported the literature and fifth hypothesis of this study. Comparatively moderate significant negative $(r=-0.515)$ relationship is discovered. And creative accounting has accounted for $46 \%(\beta=-0.462)$ of reliability and objectivity of financial reporting. 


\section{Conclusion}

From literature review, analysis results and discussion it is concluded that creative accounting practices exercised in Pakistan for preparation of financial reporting. Owner manager is the manager reason of adoption of such manipulative activities as well as corporate governance also play important role. Company's ethical values also have moderate influence on the alteration of books of accounts but results of study claims that company's future orientation has minimal impact of creative accounting and financial reporting. Creative accounting has significant impact on reliability as well as objectivity of financial reporting. To control such manipulative activities, owners have to focus on controlling the agency problem. As well as strong corporate governance strengthen the ethical values in the company and minimize the negative use of creative accounting. If creative accounting practiced in limited and positive way then it will not destruct the core purpose of financial reporting.

\section{Limitations and Future Research}

This study is generalized on the basis of data collected from Punjab region but it can further strengthen if other provinces also covered in analysis. Furthermore, only manufacturing industry is studied. It can be studied in other sectors of the economy with other variables like government regulations, auditors comment, financial literacy etc.

\section{References}

Afolabi, A., Oluseye, M. (2013). "Effect of financial reporting on investment decision making of manufacturing firms in nigeria." European Journal of Humanities and Social Sciences, 22(1), 11271142.

Amat, O., Gowthorpe, C. (2004). "Creative accounting: nature, 1ncidence and ethical 1ssues.” Journal of Business Ethics, 57, 55-64.

Carl, S., Reeve, J., Duchac, J (2008).“Financial Accounting.” Publisher: South-Western College Pub. 920 p. ISBN $978-032-466-378-5$. p. 387

Chen, S. (2010). "The role of ethical leadership versus institutional constraints: a simulation study of financial misreporting by CEOs.” Journal of Business Ethics, Springer, 93(2), 33-52.

C. Jean (2011), "The Impact of the Corporate Governance Code on Earnings Management: Evidence from Chinese Listed Companies.” EFMA Symposium, pp.1-62, 2011.

Diana, B., Beattrice, V.A. (2010). "Creative accounting - players and their gains and losses." Annuals of Faculty of Economics, 1(2), 813-819.

Efiok, S.O., Eton, O.E. (2012). "Creative accounting and managerial decision on selected financial institutions in Nigeria." International Journal of Business Research and Management, 3(1), 35 47.

FizzaTassadaq, Qaisar Ali Malik (2015). "Creative Accounting and Financial Reporting: Model Development and Empirical Testing." International Journal of Economics and Financial Issues, 2015, 5(2), 544-551.

Gherai, D.S., Balaciu, D.E. (2011). "From creative accounting practices and Enron phenomenon to the current financial crisis." Annuals Series Of Economics, 13(1), 34-41.

Jameson, M. (1988).“A practical guide to creative accounting."

Karim, A. M., Fowzia, R., \& Rashid, M. M. (2011). "Cosmetic Accounting Practice in Developing Countries Bangladesh Preventives.” World Journal of Social Sciences, Australia, 1(3), 1- 15.

Karim and Junaid (2014). "Creative Accounting - a form of manipulating." 1(1), 1 -15

Laura Maria Popescu and Ileana Ashrafzadeh (2013). "Detecting Creative Accounting Practices and their Impact on the Quality of Information Presented in Financial Statements." Journal of Knowledge Management, Economics and Information Technology.Vol.3 Iss. 6.2013

Merchant, K .A. and Rockness, J. (1994). "The ethics of managing earnings: empirical investigation." 
Journal of Accounting and Public Policy,13, 79-94.

Mulford, C.W., Comiskey, E.E. (2002). "The Financial Numbers Game, Detecting Creative Accounting Practices."Canada: John Wiley" \&Sons.Inc.

Mulford, Ch., Comiskey, (2005). "The Financial Numbers Game: Detecting Creative Accounting Practices." Publisher: Wiley. 408 p. ISBN 978-047-177-073-2.p. 47.

Shah, A. K. (1988). "Exploring the influences and constrains of Creative Accounting in the UK." Euorpean Accounting Review, Vol. 7, 1,Pp .83-104.

Shah, S., Butt S., Tariq, Y.B. (2011). "Use or abuse of creative accounting techniques." International Journal of Trade, Economics and Finance, 2(6), 531-536.

Sorin, B., Ramona, R.P., Adrian, G. (2012). "Qualitative study regarding the relationship between corporate governance and creative accounting." Annuals of Faculty of Economics, 1(2), 642647.

Watts, R.L., Zimmerman, J.L. (1990). “Positive accounting theory: a ten year perspective.” Accounting Review, 65(1), 131-156.

Yadav, B. (2013). "Creative accounting: a literature review." The SIJ Transactions on Industrial, Financial and Business Management (IFBM), 1(5), 181-193.

Yadav, B., Kumar, A., Bhatia, B.S. (2014). "Concept of creative accounting and its different tools." International Journal of Management and Social Sciences Research (IJMSSR), 3(2), 66-74. 